\title{
Economic Determinants of Capital Flight in Jordan: An Empirical Study
}

\author{
Ameen B. Al-basheer \\ Department of Finance and Banking Sciences, Faculty of Business \\ Administration, Ajloun National University, Jordan \\ Torki M. Al-Fawwaz \\ Finance and Economic Department, Faculty of Finance and Business \\ Administration, Al al-Bayt University, Mafraq, Jordan \\ Ateyah M. Alawneh \\ Department of Finance and Banking Sciences, Faculty of Business \\ Administration, Tafila Technical University, Jordan
}

doi: 10.19044/esj.2016.v12n4p322 URL:http://dx.doi.org/10.19044/esj.2016.v12n4p322

\begin{abstract}
The aim of this study is to estimate the constraints of Capital Flight during the period from 2000 to 2013. The statistical analysis showed a positive statistical significant relationship between the external public debt, taxes, economic openness, previous capital flight, and Capital flight in Jordan. However, it also showed a negative statistical significant relationship between the growth rate of the economy and capital flight. This was together with the most important recommendations of the need to monitor the flight of capital through creating a Department in the central bank to control money flight. Therefore, this was aimed in reducing the external public debts that increase the phenomenon of Capital flight and cooperate with international institutions and the United Nations to locate the place of money flight.
\end{abstract}

Keywords: Capital Flight, The Constraints of Capital Flight, inflation, Gross Domestic Product (GDP)

\section{Introduction}

The subject of migration of capital from developing countries in general and the Arab in particular, is a very important topic. However, this is because these countries have worked during the past periods to reduce the migration of these funds abroad. Also, they have employed economic reforms' policies in order to attract foreign capital. Despite these efforts, Capital Flight still remains a growing phenomenon in these countries, which indicates that these reform policies did not come to fruition, and did not 
achieve their goal. This research is aimed to look into the causes and constraints of capital flight in Jordan. However, this is accomplished by a standard study to record the impact of these constraints on capital flight in this country.

\section{Study Problem}

The problem of the study is represented in determining the economic constraints of capital flight in Jordan, and the impact of each of these constraints on the capital flight. In addition, the study problem stems from measuring the impact of these constraints on the economic capital funds in Jordan.

\section{The Significance of the Study \& its Objectives}

The importance of the study emerged from the growing interest in the capital flight and the need to discover the reasons and constraints of capital flight, especially from developing countries. This basically occurs as a result of the damage caused by the escape of these funds, inadequate savings, and the lack of foreign exchange resources in achieving economic development.

\section{The research also aims at}

1 - Studying the constraints of capital flight.

2 - Indicating the impact of each specific constraints of capital flight.

3 - Working on setting a special indicator to estimate and measure the size of capital flight from Jordan.

\section{Hypotheses of the Study} hypotheses:

Consequently, the research emerged from the following main

1 - There is no statistical significant relation between foreign debt and capital flight in Jordan.

2 - There is no statistical significant relation between the previous capital flight and capital flight in Jordan.

3 - There is no statistical significant relation between trade openness and capital flight in Jordan.

4 - There is no statistical significant relation between Gross Domestic Product growth rate and the capital flight in Jordan.

5 - There is no statistically significant relation between tax revenues and capital flight in Jordan.

6 - There is no statistical significant relation between inflation and capital flight in Jordan. 


\section{Methodology of the Study}

The scientific insights in research and recent studies were adopted on the scientific method based on the study and analysis of the factors and the different variables related to the research questions. Therefore, we will use the descriptive method and reasoning approach on both types: inductive and deductive. Furthermore, this is in addition to the quantitative analysis approach (standard) which is sometimes referred to as the historical approach.

\section{Literature Review}

Schneider (2003) calculated capital flight in 116 countries between 1971 and 1998.

This study is based on the estimation of the capital flight on some key variables such as changes in the volume of foreign debt, net foreign investment, current account surplus, and change in the reserves. Subsequently, this study found that capital flight has increased during the nineties than in the eighties and seventies, especially in East Asia and Latin America. This increase occurs for various reasons and varies from one country to another.

Boyce and Ndikumana( 2010) present estimates of the volume of capital flight from 33 African countries, Sub-Saharan. During the period from 1970 to 2004, and by estimating the difference between cash inflows and outflows of foreign exchange in the balance of payments and with the volume of net borrowing, as well as the recorded and unrecorded remittances that are registered in these countries, this study has concluded that the capital flight size of these countries reached \$ 443 billion in 2004. However, this is with a cumulative size of these funds which reached $\$ 640$ billion. Also, this exceeded the debt of these countries in 2004 and amounted to \$ 193 billion.

Arene and Usman (2014) examine the impact of capital fight and its macroeconomic determinants on agricultural growth in Nigeria from 1970 2013. The results indicate that a unit change in EXD will bring about $24 \%$ changes in the growth of agriculture provided other factors are kept constant. Political instability (POL) variable has negative and significant effect on agricultural growth in Nigeria.

Cerra, and Saxena(2005) test whether unsound macroeconomic policies or weak institutions lead to capital flight, using panel data for a large set of developing, emerging market and transition countries. The results indicate that FDI and aid tend to reduce flight. Short-term debt accumulation has the most severe impact on capital flight. Also the result showed that macroeconomic policy variables and conditions have a significant influence on capital flight, even after controlling for country effects and institutional 
quality. Institutional quality, particularly effective institutional constraints on executive power, has an independent impact on capital flight.

El-Mittieri and El-Sakka (2009) examine the relationship between macro- economic determinants and capital flight from Kuwait. The study found that the main factors affect the capital flight from Kuwait are: Financial restraint, Inflation rates, Kuwaiti dinar exchange rate, political and economic instability, and level of smuggling.

\section{What is New in this Research?}

The researcher believes that what distinguishes his current study from all the above studies lies basically on two key points. The first point considers the time period which this current study is based upon (2000-2013) in the Hashemite Kingdom of Jordan. The second point lies in using quantitative statistical methods and topics inferential statistics, including hypotheses test that have not been used by all of the studies mentioned above. Thus, this makes the current research results to be of great reliability because it depends on using sound scientific methods.

\section{Results}

\section{First: The Definition of Capital Flight}

Capital flight can be defined in a simple manner as the flow of funds abroad as a result of economic and political instability (Schneider 2003).

Ndikumana and Boyce (2002) also defined capital flight as residents' capital outflows, excluding recorded investment abroad. Aziz (2014) defined capital flight in terms of domestic and foreign investors' response to an asymmetric risk of expropriation. Assuming that there is no cost related to foreign investment, a two-way capital flow is observed where domestic investors invest abroad in order to avoid higher risk of expropriation while using foreign funds to finance domestic investment.

\section{Second: The Constraints of Capital Flight}

1. Foreign Debt: Increasing foreign debt leads to the accumulation of the growing phenomenon of capital flight abroad. Therefore, this is because these debts have led to a weakening in the financial resources of these countries (especially the developing ones). Contrary to what was expected of these debts, which were supposed to increase the financial resources for these countries, (Ajilore ,2005;Cuddington ,1986; and Dooley 1988) stated through their applied studies that $50 \%$ of the increase in the foreign debt of Argentina, Mexico, and Venezuela during the period from 1974 to 1982, has drained through the flow of capital abroad. 
2. Capital Flight in previous years: Researchers agree that the capital flight in previous years significantly affect the flight of the current capital. Thus, a huge capital flight in previous years will lead to more flying in the current capital, (KOLAPO and OJO,2012).

3. Trade Openness: Helps to increase the capital flight from inside the country to outside the country. This is especially common in developing countries, or those countries which passes through stages of economic transformation, and through the removal of imposed restrictions on foreign trade and foreign exchange transactions. Therefore, this makes releasing and opening of foreign trade possible, and the transfer of funds abroad easier. This promotes capital flight, as it allows individuals to transfer money abroad in legal ways, where they are recorded in current account balance. In addition, it works on the integration of the local and foreign capital markets, thereby reducing the differences between local and foreign revenues of investors, (Fofack and Ndikumana, 2014).

\section{Gross Domestic Product Growth Rate}

The decline of GDP growth rates leads to capital flight, due to the emergence of a pessimistic atmosphere among the owners of these funds. Therefore, they must find safer places to invest these funds, as capital flight hinders the economic and social development process. This arises due to lack of financial resources to achieve this economic development, which will reflect negatively on GDP growth rates. Furthermore, this would lead to its decline, which means that there is an inverse relationship between GDP and capital flight growth rates. Thus, as the rate is increased, the GDP growth rate will be lowered, and the relationship between them is reciprocal, (Boyce and Ndikumana, 2012).

\section{Tax Policy}

Capital flight may arise to avoid high taxes. The income generated from domestic assets will always be exposed to a tax on incomes, since the higher tax rates on the incomes unrealistically encourage tax evasion. Also, it transfers capital abroad to avoid high taxes on incomes, (O'Hare, et al. 2014).

\section{Inflation}

The expectations of individuals about the rate of inflation in the future affect the amount that individuals would like to keep from cash balances in local currency, Davies (2008) indicates that if the expected inflation rate rose, and there was no adjustment of interest rates to cover 
these inflationary expectations, then individuals tend to convert their money into real assets.

It was noted that developing countries in general lacks an organized broad financial markets, which means that the assets available for investment are limited to real money and assets. Consequently, it is also limited to the capital flight abroad when they are not looking attractive for investment assets.

According to the model of demanding money, when there is an increase rate of inflation, or when individuals expects an increase in the rate of inflation in the future, it is expected that the individuals must reduce their holdings of cash balances and shift to assets to ensure some sort of protection against inflation. This entails real assets, releasing currency or smuggling their capital abroad, if releasing opportunity is unavailable.

Table (1). Economic Constraints of Capital Flight in Jordan

\begin{tabular}{|c|c|c|c|c|c|c|c|c|}
\hline Year & $\begin{array}{c}\text { Gross } \\
\text { domestic } \\
\text { product }\end{array}$ & $\begin{array}{c}\text { M.N.M } \\
\%\end{array}$ & $\begin{array}{l}\text { The } \\
\text { percentage } \\
\text { of tax } \\
\text { revenues } \\
\text { from the } \\
\text { gross } \\
\text { domestic } \\
\text { product }\end{array}$ & $\begin{array}{c}\text { Tax } \\
\text { revenues }\end{array}$ & $\begin{array}{l}\text { The } \\
\text { percentage } \\
\text { of gross } \\
\text { domestic } \\
\text { product }\end{array}$ & $\begin{array}{c}\text { The } \\
\text { balance } \\
\text { of } \\
\text { external } \\
\text { debt }\end{array}$ & $\begin{array}{c}\text { Trade } \\
\text { Openness } \\
\%\end{array}$ & $\begin{array}{c}\text { Inflation } \\
\%\end{array}$ \\
\hline 2000 & 5989.2 & - & 0.7 & 76.7 & 5043.5 & 84.2 & 961.9 & 16.1 \\
\hline 2001 & 6339 & 5.8 & 1.8 & 80.1 & 4969.8 & 78.4 & 996.4 & 15.7 \\
\hline 2002 & 6794 & 7.2 & 1.8 & 81.9 & 5350.4 & 78.8 & 1000.3 & 14.8 \\
\hline 2003 & 7228.8 & 6.4 & 2.3 & 85.9 & 5391.8 & 74.6 & 1083.2 & 15 \\
\hline 2004 & 8090.7 & 11.9 & 2.6 & 105.7 & 5348.8 & 66.1 & 1428.800 & 17.7 \\
\hline 2005 & 8925.4 & 10.3 & 3.5 & 117.5 & 5056.7 & 56.7 & 1765.800 & 19.8 \\
\hline 2006 & 10675.4 & 19.6 & 6.3 & 111.2 & 5186.5 & 48.6 & 2133.500 & 20 \\
\hline 2007 & 12131.4 & 13.6 & 4.7 & 113.6 & 5253.3 & 43.3 & 2472.100 & 20.4 \\
\hline 2008 & 15593.4 & 28.5 & 13.9 & 113.4 & 3640.2 & 23.3 & 2758.100 & 17.7 \\
\hline 2009 & 16912.2 & 8.4 & -0.7 & 86.5 & 3869.0 & 22.9 & 2884.000 & 17.1 \\
\hline 2010 & 18762 & 10.9 & 5 & 85.5 & $4,610.8$ & 24.6 & 2986.300 & 16 \\
\hline 2011 & 20476.6 & 9.1 & 4.4 & 93.4 & $4,486.8$ & 21.9 & 3062.200 & 15 \\
\hline 2012 & 21965.5 & 7.2 & 4.7 & 92.5 & $4,932.4$ & 22.5 & 3351.400 & 15.3 \\
\hline 2013 & 23851.6 & 8.5 & 5.6 & 89.2 & $7,234.5$ & 30.3 & 3652.4 & 15.3 \\
\hline
\end{tabular}

Source: Prepared by the researcher, depending on the Central Bank of Jordan data for various years.

\section{Third: Estimation of capital Flight in Jordan}

However, we can measure the long-term of capital flight through the following World Bank equation:

\section{LCF $\triangle=$ D+FI - CAD - FR $\Delta$}

\section{Whereas:}

LCF: Long-term Capital Flight

$\mathrm{D} \triangle$ Change in Foreign Debt

FDI: Direct Net Foreign Investment

CAD: Current Account Deficit

$\triangle F$ R: Change in foreign reserves 
This study will be based on measuring the capital flight as measured by the World Bank. This is because it leads to similar results with the World Bank findings of the appropriate measure of all developing countries.

However, the long-term capital flight in Jordan is being measured based on the equation of The World Bank (1983) as shown in the table below:

Table (2). The long-term estimated capital flight in Jordan during the period (1992-2009) by Million Dollars

\begin{tabular}{|c|c|c|c|c|c|}
\hline $\begin{array}{c}\text { Capital flight } \\
\text { estimated by the } \\
\text { equation of The } \\
\begin{array}{c}\text { World Bank } \\
\text { (LCF) }\end{array}\end{array}$ & $\begin{array}{c}\text { Change in } \\
\text { foreign } \\
\text { reserves } \\
\text { FR } \\
-467.2\end{array}$ & $\begin{array}{c}\text { Current } \\
\text { Account } \\
\text { (CAD) }\end{array}$ & $\begin{array}{c}\text { Direct Net } \\
\text { Foreign } \\
\text { Investment } \\
\text { (FDI) }\end{array}$ & $\begin{array}{c}\text { Change in } \\
\text { foreign } \\
\text { reserves } \\
\text { EXD }\end{array}$ & Year \\
\hline-710.7 & 628.6 & 19.5 & 647.5 & -466.6 & 2000 \\
\hline 54.9 & 138.9 & -17.7 & 194 & -73.7 & 2001 \\
\hline-348.6 & 427.7 & 355.7 & 168.9 & 380.6 & 2002 \\
\hline-480.3 & 1073.8 & 27.7 & 664.2 & -43 & 2003 \\
\hline 2408.1 & 317.4 & -1610.6 & 1407 & -292.1 & 2005 \\
\hline 3675.3 & 191 & -1223.8 & 2512.7 & 129.8 & 2006 \\
\hline 2556.5 & 1407.4 & -2038 & 1859.1 & 66.8 & 2007 \\
\hline 1379.3 & 458.5 & -1445.2 & 2005.7 & -1613.1 & 2008 \\
\hline 3516 & -765.3 & -799 & 1722.9 & 228.8 & 2009 \\
\hline 3457.2 & -1071.8 & -1336.3 & 1172.1 & -124 & 2010 \\
\hline 5926.7 & -2336.1 & $1336.3-$ & 1046.2 & 445.6 & 2011 \\
\hline 3169.9 & 3541.1 & $2098.8-$ & 1063.1 & 2302.1 & 2012 \\
\hline 2909.9 & 1574.1 & $3345.8-$ & 1240.7 & 795.6 & 2013 \\
\hline
\end{tabular}

Source: The Central Bank of Jordan from different issues, the change has been calculated by the researcher.

These were calculated by the researcher according to the previous equation:

Positive sign for the long-term capital flight: Means capital flight abroad.

Negative sign for the long-term capital flight: Means the return of capitals from abroad.

It was noted from table (1) that the long-term capital flight during the period of the study rose from one period to another, as the estimated numbers of the positive capital flight showed. Thus, this means that there are funds that are still flying outside the Jordanian economy, while the negative signal for the estimated numbers of capital flight means a return of capital flight to the Jordanian economy. 
Therefore, we can notice from the previous table that the capital flight returned to Jordan in 2000, with the value of 467.2 million Dinar, while the total capital flight funds was valued at 2408.1 million Dinar in 2005 due to the lack of economic stability. Hence, it continued to fly until it reached 2556.5 million in 2007, while the total money that was returned to Jordan was 38268.4 and 82548.4 million Dinar during 2010 and 2011, respectively. This is due to the trust and support of the Jordanian economy. Also, the capital flight rose in the year 2011, which amounted to 5926.7 million, while it reduced to 3169.9 and 2909.9 million Dinar during 2012 and 2013, respectively. However, this was with the aim of improving the economic position in Jordan.

\section{Fourth: The Standard Analysis of the Constraints of Capital Flight}

We will be relying on the multiple linear regression method and using E-views program to study the impact of independent variables on capital flight where the following model has been designed.

$\mathrm{CF}=\mathrm{F}$ (FD, GDPG ,I,OP,T,CF-t)

Whereas:

CF: Capital Flight by Million Dinar

FD: Foreign Debt by Million Dinar

GDPG: Gross Development Product Growth Rate

I: Inflation Rate

OP: Openness of Trade

T: Tax Revenues

CFt-1: Previous Capital Flight

Based on the findings of the researcher, we can write the multiple regression equation as follows:

$\Delta \mathrm{CF}=\mathrm{a} 0+\mathrm{B} 1 \Delta \mathrm{FD}(-2)+\mathrm{B} 2 \mathrm{LCF}(-2)+\mathrm{B} 3 \Delta \mathrm{op}(-2)+\mathrm{B} 4 \Delta \mathrm{GDPG}(-6)+$ B6Inf(-5) + B5 $\Delta \mathrm{T}(-5)+\mathrm{E}$

Whereas B1, B2, B3, B4, B5, and B6 are partial regression coefficients of independent variables which can through their signs, determine the direction of the relationship between the independent variable and the dependent variable.

Multiple linear regression method has been relied on studying the impact of the independent variables on the national investment using E-views model. Thus, the model has been estimated and the results appeared as follows.

$\mathbf{C F}=256.52+0.265 \Delta \mathbf{F D}(-2)+0.455 \Delta \mathbf{l d f}(-2)+52.64 \Delta \mathbf{o p}(-2)-9$ $\Delta$ GDPG $(-6)+4.42 \Delta \mathrm{T}(-2)+7.59 \Delta \mathbf{I N F}$. 
Table (3) The Regression Model Results Dependent Variable: I

\begin{tabular}{|c|c|c|c|}
\hline Variable & Coefficient & t- Statistic & Prob. \\
\hline $\mathrm{D}(\mathrm{FD}, 2)$ & 0.264672 & 12.25561 & 0.0518 \\
\hline $\mathrm{D}(\mathrm{LCF}, 2)$ & 0.455471 & 41.30247 & 0.0154 \\
\hline $\mathrm{D}(\mathrm{OP}, 2)$ & 52.63972 & 38.96187 & 0.0163 \\
\hline $\mathrm{D}(\mathrm{GDPG}, 6)$ & -9.007324 & -21.00122 & 0.0303 \\
\hline $\mathrm{D}(\mathrm{TAX}, 5)$ & 4.423988 & 66.79908 & 0.0095 \\
\hline $\mathrm{D}(\mathrm{INF}, 5)$ & 7.588455 & 5.610338 & 0.1123 \\
\hline $\mathrm{C}$ & 256.5249 & 14.43651 & 0.0440 \\
\hline
\end{tabular}

R- Squared: $99 \%$

Adjusted R- Squared: 99\%

F-Statistic: 2343

Prob(F-statistic): 0.01

Durbin-Watson stat: 1.01

It is clear from the model that the Adjusted R-Squared (99\%) shows that changes in the independent variables, together explains about $99 \%$ of the developments in the variable changes. For F-statistic value, its value reached 2343 with zero value of the probability of F-statistic. Therefore, this means that the model is statistically significant. In addition, Darben - Watson (DW) amounted to 1.01 . This means that the model is suitable and statistically significant where there is no existence of autocorrelation problem.

\section{Test of Hypotheses} Flight

1 - First Hypothesis: The Impact of Foreign Public Debt on Capital

It was shown from the standard estimation of the model that the relationship between the foreign public debt and the change of capital flight is positive. When the estimated coefficient of the foreign public debt has reached 0.264672 , the relationship is positive between the impact of a change in the foreign public debt to the change in capital flight. Thus, this result was consistent with the literature or the financial and economic theories which found a positive relationship between the foreign public debt and capital flight.

Based on T-Test, this result has a statistical significance at the level of $10 \%$. Therefore, this means that the confidence level for this variable is equal to $90 \%$. As a result, we can accept the hypothesis which stipulates that there is a positive relationship between the foreign public debt and capital flight.

2- Second Hypothesis: The Impact of Capital Flight in the Past on Capital Flight.

It was shown from the standard estimation of the model that the relationship between capital flight in the past and the change in the capital 
flight is positive. The estimated coefficient of the impact of capital flight in the past has reached 0.45 , which means that the relationship is positive between the impact of a change in capital flight in the past on the change of capital flight. Therefore, this result is consistent with the literature or the financial and economic theories which shows a positive relationship between capital flight and capital flight in the past.

Based on T-Test, this result has a statistical significance at the level of $5 \%$, which means that the confidence level for this variable is equal to 95\%. Thus, we can accept the hypothesis which stipulates that there is a positive relationship between capital flight in the past and capital flight. Flight

3 - Third Hypothesis: The Impact of Trade Openness on Capital

It was shown from the standard estimation of the model that the relationship between trade openness and change in capital flight is positive as the estimated impact of trade openness has reached 52.64. Thus, this means that the relationship is positive between the impact of change in trade openness to the change in capital flight. This result is consistent with the literature or the financial and economic theories which concluded that there is a positive relationship between trade openness and capital flight.

Based on T-Test, this result has a statistical significance at the level of $5 \%$, which means that the confidence level for this variable is equal to $95 \%$. Thus, we can accept the hypothesis which stipulates that there is a positive relationship between the foreign public debt and capital flight.

Flight

4. Fourth Hypothesis: The Impact of Economic Growth on Capital

It was shown from the standard estimation of the model that the relationship between the economic growth rate and the change in the capital flight is negative, since the estimated coefficient of the impact of economic growth rate has reached -9.01 . Thus, this means that the relationship is negative between the impact of a change in economic growth to the change in capital flight. This result is consistent with the literature or the financial and economic theories which found a negative correlation between the rate of economic growth and capital flight.

Based on the T-Test, this result has a statistical significance at the level of $5 \%$, which means that confidence level for this variable is equal to $95 \%$. Thus, we can accept the hypothesis which stipulates that there is a positive relationship between the rate of economic growth and capital flight.

5. Fifth Hypothesis: The Impact of Taxes on Capital Flight

It was shown from the standard estimation of the model that the relationship between taxes and the change in the capital flight is positive as the estimated coefficient of the tax impact has reached 4.42. Thus, this means that the relationship is positive between the impact of a change in the 
taxes on the change in capital flight. This result is consistent with the literature or the financial and economic theories which found a positive relationship between taxes and capital flight.

Based on T-Test, this result has a statistical significance at the level of $1 \%$, which means that the confidence level for this variable is equal to 99\%. Thus, we can accept the hypothesis which stipulates that there is a positive relationship between taxes and capital flight.

6. Sixth Hypothesis: The Impact of Inflation on Capital Flight

It was shown from the standard estimation of the model that the relationship between the inflation rate and the change in the capital flight is positive. However, this result is consistent with the literature or the financial and economic theories which found a positive relationship between inflation and capital flight, but does not have a statistical significance in any of the statistical confidence levels.

\section{Conclusion and Recommendations}

Based on the above results, we can conclude on the following results recommendations:

\section{Conclusion}

1. There is a positive relationship with statistical significance between the foreign public debt and capital flight, and the result is consistent with the financial and economic theories.

2. There is a positive relationship with statistical significance between capital flight in the past and capital flight, and the result is consistent with the financial and economic theories.

3. There is a positive relationship with statistical significance between trade openness and capital flight, and the result is consistent with the financial and economic theories.

4. There is a negative relationship with statistical significance between the rate of economic growth and the capital flight, and the result is consistent with the financial and economic theories.

5. There is an existence of a positive relationship with a statistical significance between taxes and capital flight, and the result is consistent with the financial and economic theories.

6. There is a positive relationship with statistical significance between inflation and the capital flight. Thus, the result is consistent with the financial and economic theories, but does not enjoy a statistical coefficient.

\section{Recommendations}

Finally, the study recommends the need to monitor the capital flight through creating a Department in the Central Bank to control capital flight, 
work to reduce the foreign public debt that increases the phenomenon of capital flight, cooperation with international institutions and the United Nations to determine where the capital flight, and developing an appropriate strategies to return the capital flight. The study also recommends the need to create more stability and security of the Islamic deeds (Sukuk) to limit the phenomenon of capital flight and encourage the owners of investment funds.

\section{References:}

Bernadette O’Hare , Innocent Makuta , Naor Bar-Zeev , Levison Chiwaula and Alex Cobham .(2014). The effect of illicit financial flows on time to reach the fourth Millennium Development Goal in Sub-Saharan Africa: a quantitative analysis. Journal of the Royal Society of Medicine, 107(4), 148156.

Boyce, J.K. and L. Ndikumana.( 2012). Capital Flight from Sub-Saharan African Countries: Updated Estimates, 1970-2010.Political Economy Research Institute. Working paper Series,pp.1-24.

Central Bank of Jordan, various issues.

Cuddington, J. (1986) .Capital Flight: Estimates, Issues, and Explanations.Princeton University, Princeton Studies in International Finance, No. 58 . Retrieved at: http://books.google.com/ books/about/capital-flight.html?id=.

Dooley, M .(1988) . Capital Flight: A Response to Differences in Financial Risks . IMF Staff Papers, Vol. 35, pp 422-36 .

F.T.KOLAPO and OKE, MICHEAL OJO.(2012). Nigerian Economic Growth and Capital Flight Determinants. Asian Journal of Business and Management Sciences, 1 ( 11 ),76-84.

Hippolyte Fofack and Léonce Ndikumana. (2014). Capital Flight and Monetary Policy in African Countries. The Political Economy Research Institute (PERI). Working paper Series. Number 362,pp.1-39.

Jordan Department of Statistics, various issues

Khan, M. \& Ul-Haque, N. (1985) .Foreign Borrowing and Capital Flight . IMF Staff Papers, Vol. 32. pp. 606-28.

Laidler, D. (1985) . The Demand for Money: Theories, Evidence and Problems . Harper, \& Row Publishers. 3rd ed.

Lensink, R., Hermes, N. and Murinde V. (1998). The effects of financial liberalization on capital flight in African economies. World Development, 26( 7), 1349-1368.

Naief Al-Mtairi and Mohammad Ibrahiem Al-Saqa.(2009). Determinants of Hot Money Outflow from Kuwait. Journal of the Social Sciences, 27( 2) , 31-60. 
Ndikumana, L. \& J.K. Boyce. (2002).Public Debts and Private Assets . Explaining Capital Flight from Sub-Saharan African Countries. PERI Working Paper, 32.

Ndikumana, L. and J.K. Boyce .(2010) .Measurement of capital flight: methodology and results for sub-Saharan African countries. African Development Review ,22 (4), 471-81.

OT Ajilore. (2005).External debt and capital flight in Nigeria: Is there a revolving door?. South African Journal of Economic and Management Sciences, 8( 2) , 211-244.

Saxena,S . and M, Rishi and V, Cerra.(2005). Robbing the Riches: Capital Flight, Institutions, and Instability. IMF Working Papers 05/199. International Monetary Fund.

Schneider, Benu. (2003). Measuring Capital Flight: Estimates and Interpretations; London: Overseas Development Institute, Working Paper No. 194.

Shawkatul Islam Aziz.(2014). Determinants of Capital Flight in Bangladesh: an Econometric Estimation. Developing Country Studies, 4(25), 121-134.

Usman , F. and C, Arene .(2014). Effects of Capital Flight and its Macroeconomic Determinants on Agricultural Growth in Nigeria (19702013). International Journal of Food and Agricultural Economics , 2 (4), 107-126.

Victor A.B. Davies (2008 ).Postwar Capital Flight and Inflation. Journal of Peace Research , 45 ( 4), 519-537. 